\title{
PENGEMBANGAN MODEL TAHAPAN DIGITAL FORENSIC UNTUK MENDUKUNG SERANG SEBAGAI KOTA BEBAS CYBERCRIME
}

\author{
Vidila Rosalina ${ }^{1}$, Dadang Herli ${ }^{2}$ \\ ${ }^{1)}$ Fakultas Teknologi Informasi, Universitas Serang Raya \\ ${ }^{2)}$ Fakultas Teknologi Informasi, Universitas Serang Raya \\ Jl. Raya Serang - Cilegon Km. 05 (Taman Drangong), Serang - Banten \\ e-mail: vidila.suhendarsah@gmail.com ${ }^{1}$,dhs203040@gmail.com ${ }^{2}$
}

\begin{abstract}
ABSTRAKS
Dalam Digital Forensic terdapat empat tahapan pada proses implementasi yang harus diikuti sepanjang proses investigasi Digital Forensics berlangsung yaitu: identifikasi, penyimpanan, analisa, dan presentasi. Tahapan implementasi Digital Forensic yang selama ini dipublikasikan belum pada tingkat memberikan gambaran detail pada tahapan analisis. Dalam makalah ilmiah ini, penulis melakukan pengembangan model pada tahapan ketiga pada saat analisa dengan menggunakan Zachman Frameworks untuk memberikan potret tentang bagaimana sebaiknya tahapan analisa tersebut dapat memberikan hasil secara lengkap dan menyeluruh. Selain itu, model tahapan Digital Forensik yang diusulkan sudah dapat memfasilitasi beberapa kaidah dasar yang disampaikan dalam PERKAP No. 10 Tahun 2010 tentang tata cara pengelolaan barang bukti digital, Pasal 5-6 Bab III UU ITE tentang pengakuan informasi/dokumen elektronik sebagai alat bukti hukum yang sah, serta Pasal 42-44 Bab X tentang penyidikan barang bukti elektronik atau dokumen elektronik.
\end{abstract}

Key words: Cibercrime, Digital Forensik, Pengembangan Model, Zachman Framework

\section{PENDAHULUAN}

Dengan dibentuknya Asosiasi Forensik Digital Indonesia (AFDI) oleh Kementrian Komunikasi dan Informatika pada tanggal 17 November 2015 yang lalu hal ini membuktikan bahwa Digital Forensik merupakan bidang ilmu baru dalam dunia komputer yang berkembang pesat akhir-akhir ini dengan makin maraknya kejahatan di bidang komputer serta semakin banyaknya buku-buku yang mengupas mengenai digital forensik, sehingga semakin menambah refrensi pengetahuan bagi peneliti-peneliti muda. Dengan lahirnya Undang-undang Informasi Transaksi Elektronik nomor 11 Tahun 2008, maka semakin membuat bidang ilmu ini menjadi perangkat wajib untuk membongkar kejahatan yang melibatkan dunia komputer, karena pada umumnya kejahatan komputer ini meninggalkan jejak digital, maka perlu adanya seorang ahli komputer forensik yang akan mengamankan barang bukti digital atau biasa disebut digital evidence. Komputer Forensik tentu memerlukan suatu standart operational procedure (SOP) dalam mengambil bukti-bukti digital agar tidak terkontaminasi pada saat data di ambil dari digital evidence sehingga sangat memudahkan para ahli komputer forensik untuk melakukan pemulihan sistem pasca kerusakan.

Menelisik lebih jauh, seperti yang pernah disampaikan oleh Dezfoli et. al (Dezfoli and A. Dehghantanha,2013) bahwa digital forensics merupakan "the procedure of investigating computer crimes in the cyber world". Sementara itu, Agarwal dalam Prayudi, Ashari, et.al (Prayudi, Y., Ashari, A.,2015) bahwa upaya pengungkapan Cybercrime dilakukan melalui proses investigasi yang dikenal dengan istilah Forensika Digital (Digital Forensics). Masih menurut Agarwal, juga menyebutkan bahwa digital forensics adalah penggunaan ilmu dan metode untuk menemukan, mengumpulkan, mengamankan, menganalisis, menginterpretasi dan mempresentasikan barang bukti digital dalam rangka kepentingan rekontruksi kejadian serta memastikan keabsahan pada proses peradilan. Jauh sebebelumnya, Palmer yang dikutip oleh Beebe \& Clark (N. L. Beebe and J. G. Clark,2005) sudah pernah menyampaikan terminologi awal dari istilah digital forensics, yaitu "The use of scientifically derived and proven methods toward the preservation, collection, validation, identification, analysis, interpretation, documentation, and presentation of digital evidencel derived from digital sources for the purpose of facilitation or furthering thereconstruction of events found to be criminal, or helping to anticipate unauthorized actions shown to be disruptive to planned operations." Salah satu aspek penting dalam pelaksanaan investitasi digital forensics adalah Scientific 
Method, artinya setiap tahapan dan langkah yang dilakukan oleh Tim investigasi ataupun oleh lembaga hukum harus menjunjung tinggi kaidah metode ilmiah. Berdasarkan beberapa definisi dan deskripsi sebelumnya, dapat dirumuskan bahwa digital forensics merupakan sebuah langkah yang terstruktur dalam melakukan proses investigasi serta penanganan barang bukti untuk meminimalkan adanya kesalahan dalam proses investigasi (EK. Mabuto and HS. Venter, 2011). Dengan berpedomankan pada karakteristik scientific method inilah, maka dalam bidang digital forensics harus mengacu pada langkah-langkah secara prosedural dan terstruktur. Oleh karena itulah, bidang digital forensics dalam perkembangan selanjutnya dikenal dengan istilah framework. Framework, dalam bahasa formalnya pernah dikemukakan oleh Petar \& Maravi (P. Čisar and S. M. Čisar, 2011) merupakan "a structure to support a successful forensic investigation”. Secara umum, di lingkungan digital forensics setidaknya ada beberapa istilah terkait dengan langkah-langkah terstruktur dalam proses investigasi, diantaranya adalah Framework, Methodology, dan Forensics Process.

\section{METODE YANG DIGUNAKAN}

Zachman Frameworks merupakan kerangka arsitekural yang paling banyak dikenal dan diadaptasi. Para arsitek data enterprise mulai menerima dan menggunakan framework ini sejak pertama kali diperkenalkan oleh John A Zachman di IBM System Journal pada tahun 1987 dan kemudian dikembangkan pada tahun 1992 dengan tujuan untuk menyediakan struktur dasar organisasi yang mendukung akses, integrasi, interpretasi, pengembangan, pengelolaan, dan perubahan perangkat arsitektural dari sistem informasi organisasi (enterprise) (Radwan, A. and Majid Aarabi , 2011)

Menurut Melissa A Cook (Cook, Melissa A.,1996), John A Machan pada akhir tahun '80-an memperkenalkan sebuah kerangka untuk membantu manajemen dalam melaksanakan dua hal utama. Hal pertama adalah untuk memisahkan antara komponenkomponen utama dalam sistem informasi agar mempermudah manajemen dalam melakukan perencanaan dan pengembangan. Sementara hal kedua adalah bagaimana membangun sebuah perencanaan strategis dari tingkat yang paling global dan konseptual sampai dengan teknis pelaksanaan. Secara prinsip Zachman membagi sistem informasi menjadi tiga komponen besar, yaitu: Data, Proses, dan Teknologi yang pada perkembangannya menjadi enam buah entiti utama. Seorang praktisi bernama John Zachman di akhir tahun '80-an menganalisa hal ini dan memberikan salah satu solusinya yang hingga saat ini masih relevan untuk dipergunakan. Untuk mengenang namanya, kerangka ini dinamakan Kerangka Zachman. Zachman Framework merupakan matrik $6 \times 6$ yang merepresentasikan interseksi dari dua skema klasifikasi - arsitektur sistem dua dimensi. Pada dimensi pertama, Zachman menggambarkannya sebagai baris yang terdiri dari 6 perspektif yaitu (Osvalds, G.,2001):

a) The Planner Perspective (Scope Context) : Daftar lingkup penjelasan unsur bisnis yang dikenali oleh para ahli strategi sebagai ahli teori.

b) The Owner Perspective (Business Concept) : Model semantik keterhubungan bisnis antara komponen-komponen bisnis yang didefenisikan oleh pimpinan eksekutif sebagai pemilik.

c) The Designer Perspective (System Logic) : Model logika yang lebih rinci yang berisi kebutuhan dan desain batasan sistem yang direpresentasikan oleh para arsitek sebagai desainer.

d) The Builder Perspective (Technology Physics) : Model fisik yang mengoptimalkan desain untuk kebutuhan spesifik dalam batasan teknologi spesifik, orang, biaya dan lingkup waktu yang dispesifikasikan oleh engineer sebagai builder.

e) The Implementer Perspective (Component Assemblies) : Teknologi khusus, tentang bagaimana komponen dirakit dan dioperasikan, dikonfigurasikan oleh teknisi sebagai implementator.

f) The Participant Perspective (Operation Classes): Kejadian-kejadian sistem berfungsi nyata yang digunakan oleh para teknisi sebagai participant.

Framework Zachman diharapkan dapat menyediakan pengertian dari aspek khusus manapun dari sebuah sistem pada sudut pandang apapun dalam pengembangan sistem. Tool ini dapat berguna untuk membuat keputusan mengenai perubahan dan penambahan. Zachman Framework mengandung enam baris dan enam kolom menghasilkan 36 sel atau aspek.

Kolom-kolom pada Zachman Frameworks mencakup (Zachman, J.A.,2012):

1. Who: merepresentasikan hubungan orang dalam perusahaan. Desain dari organisasi perusahaan harus berhubungan dengan alokasi kerja dan otoritas struktur dan tanggung jawab.

2. When: merepresentasikan waktu atau hubungan event yang membuat kriteria kinerja dan level-level kuantitatif untuk sumber-sumber perusahaan. Hal ini berguna untuk mendesain jadwal, arsitektur pemrosesan, arsitektur kontrol, dan perangkatperangkat timing.

3. Why: mendeskripsikan motivasi-motivasi perusahaan. Hal ini memperlihatkan sasaran-sasaran dan tujuan, rencana bisnis, arsitektur pengetahuan, dan desain pengetahuan. 
4. What: mendeskripsikan entitas-entitas yang terlibat di tiap perspektif perusahaan. Sebagai contoh termasuk obyek-obyek bisnis, data sistem, TabelTabel relasional dan definisi-definisi.

5. How: memperlihatkan fungsi-fungsi dalam setiap perspektif. Sebagai contoh mencakup proses-proses bisnis, fungsi aplikasi software, fungsi hardware komputer, dan bahasa control loop.

6. Where: memperlihatkan lokasi-lokasi dan interkoneksi dalam perusahaan. Hal ini termasuk lokasi geografi utama, bagian terpisah dalam jaringan logistik, alokasi dari node-node sistem atau bahkan pengalamatan memori dalam sistem.

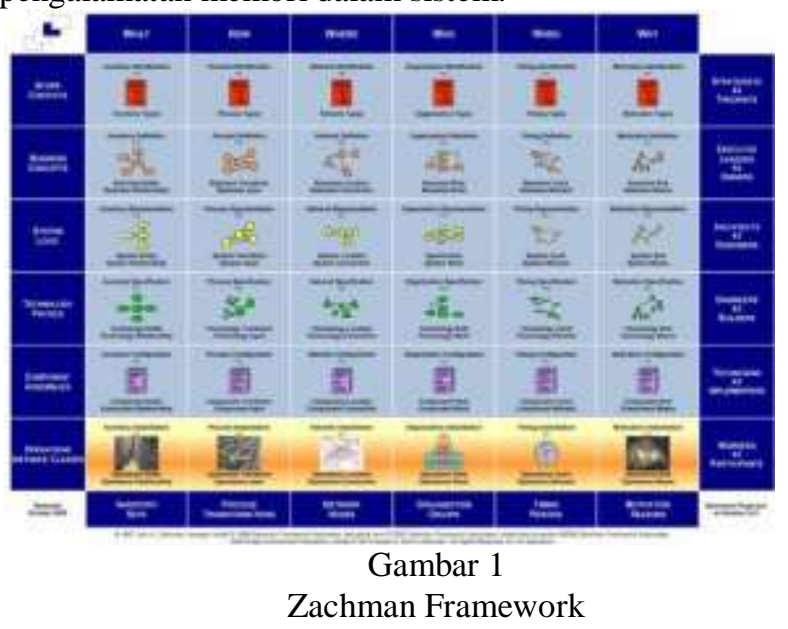

(http://zachmaninternational.com/index.php/homearticle/13)

Zachman Framework tidak memberikan model dan arsitektur khusus yang dapat digunakan untuk memberikan penjelasan lengkap. Pemakai Zachman Framework bebas memilih alat yang akan digunakan untuk menerapkan rancangan yang akan dibuat.

Menurut Kemmish (Kemmish, R. M., 2012) secara garis besar dapat diklasifikasikan menjadi empat tahapan, yaitu:

1. Identifikasi bukti digital

2. Penyimpanan bukti digital

3. Analisa bukti digital

4. Presentasi

Keempat tahapan ini secara terurut dan berkesinambungan digambarkan pada gambar berikut:

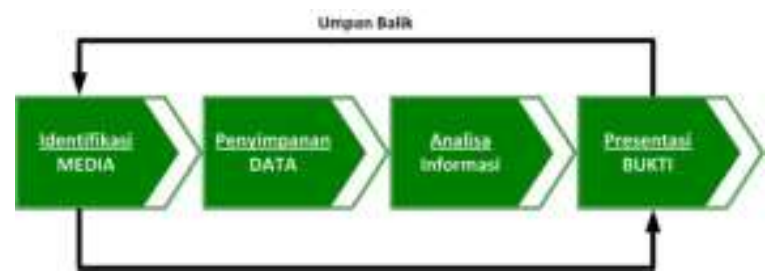

Gambar 2

Tahapan Digital Forensik menurut Kemmish

Penjelasan empat tahapan Digital Forensik menurut Kemmish:

a. Identifikasi bukti digital. Pada tahap ini segala bukti-bukti yang mendukung penyelidikan dikumpulkan. Media digital yang bisa dijadikan sebagai barang bukti mencakup sebuah sistem komputer, media penyimpanan (seperti flash disk, pen drive, hard disk, atau CD-ROM), PDA, handphone, smart card, sms, e-mail, cookies, source code, windows registry, web browser bookmark, chat log, dokumen, log file, atau bahkan sederetan paket yang berpindah dalam jaringan komputer. Tahapan ini merupakan tahapan yang sangat menentukan karena buktibukti yang didapatkan akan sangat mendukung penyelidikan untuk mengajukan seseorang ke pengadilan dan diproses sesuai hukum hingga akhirnya dijebloskan ke tahanan. Penelusuran bisa dilakukan untuk sekedar mencari "ada informasi apa disini?" sampai serinci pada "apa urutan peristiwa yang menyebabkan terjadinya situasi terkini?". Berdasarkan klasifikasinya file yang menjadi objek penelusuran terbagi kepada tiga kategori, yaitu: file arsip (archieved files), file aktif (active files) dan file sisa (residual data). File Arsip adalah file yang tergolong arsip karena kebutuhan file tersebut dalam fungsi pengarsipan. Mencakup penanganan dokumen untuk disimpan dalam format yang ditentukan, proses mendapatkannya kembali dan pendistribusian untuk kebutuhan yang lainnya, misalnya beberapa dokumen yang didigitalisasi untuk disimpan dalam format TIFF untuk menjaga kualitas dokumen. File aktif adalah file yang memang digunakan untuk berbagai kepentingan yang berkaitan erat dengan kegiatan yang sedang dilakukan, misalnya file-file gambar, dokumen teks, dan lain-lain. Sedangkan file yang tergolong residual mencakup file- file yang diproduksi seiring proses komputer dan aktivitas pengguna, misalkan catatan penggunan dalam menggunakan internet, database log, berbagai temporary file, dan lain sebagainya. Beberapa software atau tools yang bisa digunakan dalam mendukung tahapan ini antara lain:
a. Forensic
Acquisition
Utilities
(http://users.erols.com/gmgarner/forensics/)
b. FTimes(http://ftimes.sourceforge.net/FTimes/in dex.shtml)
c. Liveview (http://liveview.sourceforge.net/)
d. Netcat(http://www.atstake.com/research/tools/n etwork_utilities/pdd)
e. ProDiscoverDTF(www.techpathways.com $)$ 
f. Psloggedon(http://www.sysinternals.com/ntw2 $\mathrm{k} /$ freeware/psloggedon.shtml)

g. TULP2G(http://sourceforge.net/projects/tulp2 $\mathrm{g} /$ )

h. UnxUtils (http://unxutils.sourceforge.net)

i. Webjob(http://webjob.sourceforge.net/WebJob index.shtml).

j. dan lain sebagainya

Sedangkan rules of evidence artinya pengaturan barang bukti dimana barang bukti harus memiliki keterkaitan dengan kasus yang diinvestigasi dan memiliki kriteria sebagai berikut: pertama, layak dan dapat diterima (Admissible). Artinya barang bukti yang diajukan harus dapat diterima dan digunakan demi hukum, mulai dari kepentingan penyidikan sampai ke pengadilan. Kedua, Asli (Authentic). Barang bukti harus mempunyai hubungan keterkaitan yang jelas secara hukum dengan kasus yang diselidiki dan bukan rekayasa. Ketiga, akurat (Accurate). Barang bukti harus akurat dan dapat dipercaya. Keempat, lengkap (Complete). Bukti dapat dikatakan lengkap jika didalamnya terdapat petunjuk-petunjuk yang lengkapdan terperinci dalam membantu proses investigasi.

2. Penyimpanan bukti digital. Tahapan ini mencakup penyimpanan dan penyiapan buktibukti yang ada, termasuk melindungi bukti-bukti dari kerusakan, perubahan dan penghilangan oleh pihak-pihak tertentu. Bukti harus benar-benar steril artinya belum mengalami proses apapun ketika diserahkan kepada ahli digital forensik untuk diteliti. Karena bukti digital bersifat sementara (volatile), mudah rusak, berubah dan hilang, maka pengetahuan yang mendalam dari seorang ahli digital forensik mutlak diperlukan. Kesalahan kecil pada penanganan bukti digital dapat membuat barang bukti digital tidak diakui di pengadilan. Bahkan menghidupkan dan mematikan komputer dengan tidak hati-hati bisa saja merusak/merubah barang bukti tersebut. Sebagaimana diungkapkan Peter Plummer:

"When you boot up a computer, several hundred files get changed, the data of access, and so on. Can you say that computer is still exactly as it was when the bad guy had it last?".

Sebuah pernyataan yang patut dipikirkan bahwa bagaimana kita bisa menjamin kondisi komputer tetap seperti keadaan terakhir ketika ditinggalkan oleh pelaku kriminal manakala komputer tersebut kita matikan atau hidupkan kembali. Karena ketika komputer kita hidupkan terjadi beberapa perubahan pada temporary file, waktu akses, dan seterusnya. Sekali file-file ini telah berubah ketika komputer dihidupkan tidak ada lagi cara untuk mengembalikan (recover) file-file tersebut kepada keadaan semula. Komputer dalam kondisi hidup juga tidak bisa sembarangan dimatikan. Sebab ketika komputer dimatikan bisa saja ada program penghapus/perusak yang dapat menghapus dan menghilangkan bukti-bukti yang ada. Ada langkah-langkah tertentu yang harus dikuasai oleh seorang ahli digital forensik dalam mematikan/menghidupkan komputer tanpa ikut merusak/menghilangkan barang bukti yang ada didalamnya. Aturan utama pada tahap ini adalah penyelidikan tidak boleh dilakukan langsung pada bukti asli karena dikhawatirkan akan dapat merubah isi dan struktur yang ada didalamnya. Mengantisipasi hal ini maka dilakukan copy data secara Bitstream Image dari bukti asli ke media penyimpanan lainnya. Bitstream image adalah metode penyimpanan digital dengan mengkopi setiap bit demi bit dari data orisinil, termasuk file yang tersembunyi (hidden files), file temporer (temporary file), file yang terdefrag (defragmented file), dan file yang belum teroverwrite. Dengan kata lain, setiap biner digit demi digit di-copy secara utuh dalam media baru. Teknik ini umumnya diistilahkan dengan cloning atau imaging. Data hasil cloning inilah yang selanjutnya menjadi objek penelitian dan penyelidikan.

3. Analisa bukti digital. Tahapan ini dilaksanakan dengan melakukan analisa secara mendalam terhadap bukti-bukti yang ada. Bukti yang telah didapatkan perlu di-explore kembali ke dalam sejumlah skenario yang berhubungan dengan tindak pengusutan. Penelusuran bisa dilakukan pada data-data sebagai berikut: alamat URL yang telah dikunjungi, pesan e-mail atau kumpulan alamat e-mail yang terdaftar, program word processing atau format ekstensi yang dipakai, dokumen spreedsheat yang dipakai, format gambar yang dipakai apabila ditemukan, file-file yang dihapus maupun diformat, password, registry windows, hidden files, log event viewers, dan log application. Termasuk juga pengecekan pada metadata. Kebanyakan file mempunyai metadata yang berisi informasi yang ditambahkan mengenai file tersebut seperti computer name, total edit time, jumlah editing session, dimana dicetak, berapa kali terjadi penyimpanan (saving), tanggal dan waktu modifikasi. Selanjutnya melakukan recovery dengan mengembalikan file dan folder yang terhapus, unformat drive, membuat ulang partisi, mengembalikan password, merekonstruksi ulang halaman web yang pernah dikunjungi, mengembalikan email- email yang terhapus dan seterusnya. Tahapan analisis terbagi dua, yaitu: analisis media (media analysis) dan 
analisis aplikasi (application analysis) pada barang bukti yang ada. Beberapa tools analisis media yang bisa digunakanantara lain:
a. TestDisk(http://www.cgsecurity.org/testdisk. $\underline{\mathrm{html}})$
b. Explore2fs(http://uranus.it.swin.edu.au/ jn/li nux/explore2fs.htm)
c. ProDiscoverDFT (http://www.techpathways.com)

Sedangkan untuk analisis aplikasi, beberapa tools yang bisa digunakan seperti:

a. EventLogParser(http://www.whitehats.ca/mai n/members/Malik/malik_eventlogs/malik_eve nt logs.html)

b. Galleta(http://www.foundstone.com/resource s/proddesc/galleta.htm)

c. Libpff (http://libpff.sourceforge.net

d. Md5deep(http://md5deep.sourceforge.net/)

e. MD5summer(http://www.md5summer.org/)

f. Outport(http://outport.sourceforge.net/)

g. Pasco(http://www.foundstone.com/resources/ proddesc/pasco.htm)

h. RegRipper(http://windowsir.blogspot.com/20 08/04/updated-regripper.html)

i. Rifiuti(http://www.foundstone.com/resources /proddesc/rifiuti.htm)

4. Presentasi. Presentasi dilakukan dengan menyajikan dan menguraikan secara detail laporan penyelidikan dengan bukti-bukti yang sudah dianalisa secara mendalam dan dapat dipertanggung jawabkan secara hukum di pengadilan. Laporan yang disajikan harus di cross-check langsung dengan saksi yang ada, baik saksi yang terlibat langsung maupun tidak langsung. Hasil laporan akan sangat menentukan dalam menetapkan seseorang bersalah atau tidak sehingga harus dipastikan bahwa laporan yang disajikan benar-benar akurat, teruji, dan terbukti. Beberapa hal penting yang perlu dicantumkan pada saat presentasi/panyajian laporan ini, antara lain:

a. Tanggal dan waktu terjadinya pelanggaran

b. Tanggal dan waktu pada saat investigasi Permasalahan yang terjadi

c. Masa berlaku analisa laporan

d. Penemuan bukti yang berharga (pada laporan akhir penemuan ini sangat ditekankan sebagai bukti penting proses penyidikan)

e. Teknik khusus yang digunakan, contoh:password cracker

f. Bantuan pihak lain (pihak ketiga).

\section{PEMBAHASAN}

\subsection{Usulan Model Tahapan Digital Forensik}

Dalam makalah ilmiah ini metode yang diusulkan untuk pengembangan model tahapan
Digital Forensik dengan menggunakan Zachman frameworks yang akan diimplementasikan pada tahapan ke tiga Digital Forensik, yaitu pada tahapan Analisis. Pada makalah ini yang akan dijabarkan menggunakan 6 (enam) kolom.

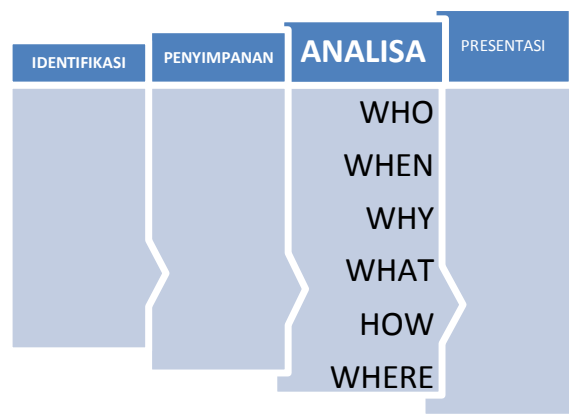

Gambar 3

Usulan Model Tahapan Digital Forensik

Pada Tahapan ke tiga digital forensik yaitu Analisis akan dijabarkan menggunakan Zachman Framework, yang dijelaskan sebagai berikut:

1. Who: menganalisis siapa saja orang yang terlibat. Siapa saja yang berhubungan dengan bukti dan otoritas struktur dan tanggung jawab. Mulai dari siapa yang mengumpulkan bukti, siapa yang memiliki bukti, siapa saja yang dapat mengakses bukti tersebut sampai siapa saja yang melakukan dan yang terlibat.

2. When: menganalisis waktu atau hubungan event yang membuat kriteria dan level-level kuantitatif untuk sumber-sumber bukti. Hal ini berguna untuk menganalisis waktu kejadian, waktu pemrosesan dan timing.

3. Why: menganalisis dan mendeskripsikan motivasimotivasi orang-orang yang terlibat berdasarkan bukti yang didapat. Hal ini memperlihatkan sasaransasaran dan tujuan, rencana pelaku.

4. What: mendeskripsikan dan menganalisis entitasentitas yang terlibat di tiap perspektif bukti yang didapat. Sebagai contoh termasuk obyek-obyek bukti, data sistem, dan definisi-definisi. Mulai dari apa yang telah dilakukan, Apa saja software yang digunakan sampai apa saja yang dihasilkan.

5. How: menganalisis dan memperlihatkan fungsifungsi dalam setiap perspektif bukti-bukti yang ditemukan. Sebagai contoh mencakup proses-proses yang telah dilakukan, fungsi aplikasi software, fungsi hardware komputer. Mulai dari Bagaimana penyimpanan dan pemeliharaan bukti itu sampai bagaimana bagaimana proses-proses dilakukan?

6. Where: menganalisis lokasi-lokasi dan interkoneksi dalam bukti digital yang ditemukan. Hal ini termasuk lokasi geografi utama, bagian terpisah dalam jaringan logistik, alokasi dari node-node 
sistem atau bahkan pengalamatan memori dalam sistem.

\section{KESIMPULAN}

Makalah ilmiah ini telah membahas tentang bagaimana pentingnya aktivitas digital forensics dalam penanganan kasus-kasus Cybercrime. Sejalan dengan semakin meningkatnya kasus Cybercrime maka tentunya harus diikuti pula dengan semakin siapnya institusi yang menjalankan aktivitas digital forensics. Dalam hal ini, salah satu yang dirasakan masih lemah dikalangan intitusi tersebut adalah belum adanya gambaran model tahapan digital forensic yang relevan untuk mengambarkan bagaimana seharusnya menjalankan tahapan aktivitas digital forensics. Model tahapan digital forensik yang diusulkan pada prinsipnya adalah pengembangan dari tahapan yang sudah ada melalui metode pendekatan enam sel Zachman Frameworks yang yang telah diusulkan, sehingga diharapkan dapat dihasilkan model tahapan yang lebih utuh dan lengkap terhadap tahapan ke tiga digital forensics. Hal ini tentunya dapat memberikan dukungan pada pihak penegak hukum untuk menangani kasuskasus Cybercrime yang semakin banyak dan semakin canggih di Indonesia pada umumnya dan di kota serang pada khususnya. Ke depan, penelitian akan dilanjutkan dan difokuskan pada bagaimana penjabaran proses digital forensic pada tiap sel dan tiap matrik Zachman Frameworks secara terperinci.

\section{PUSTAKA}

Cook, Melissa A. ,1996, "Building Enterprise Information Architectures", Prentice Hall.

E. K. Mabuto and H. S. Venter, 2011, "State of the art of Digital Forensic Techniques", in Information Security for South Africa (ISSA, pp. 1-7).

F. Dezfoli and A. Dehghantanha, 2013, "Digital Forensic Trends and Future", Int. J. CyberSecurity Digit. Forensics, vol. 2, no. 2, pp. 48-76.

Kemmish, R. M., 2012 "What is Forensic Computer". Australian institute of Criminology,Canberra. (http://www.aic.gov.au/publications/tandi/ti1 18.pdf)

N. L. Beebe and J. G. Clark, 2005, "A hierarchical, objectives-based framework for the digital investigations process", Digit. Investig., vol. 2, no. 2, pp. 147-167.

Osvalds, G. ,2001. "Definition of Enterprise Architecture", - Centric Models for The Systems Engineers, TASC Inc.
P. Čisar and S. M. Čisar, "Methodological frameworks of digital forensics", in SISY 2011 -9th International Symposium on Intelligent Systems and Informatics, Proceedings, 2011, pp. 343-347.

Prayudi, Y., Ashari, A. , 2015 "Digital Chain of Custody!: State Of The Art”, Int. J. Comput. Appl., vol. 114(5), pp. 1-9.

Radwan, A., and Majid Aarabi, 2011, "Study of Implementing Zachman Framework for Modeling Information Systems for Manufacturing Enterprises Aggregate Planning", Proceedings of the 2011 International Conference on Industrial Engineering and Operations Management, January 22 - 24, Kuala Lumpur, Malaysia.

Zachman, J.A., 12 Agustus 2012, John Zachman's Concise "Definition of the Enterprise Framework", http://www.zachman.com/aboutthe-zachmanframework.

Zifa, Zachman Framework, http://www.zifa.com 